\title{
First report of acariasis by Caparinia tripilis in African hedgehogs, (Atelerix albiventris), in Costa Rica
}

Primeiro relato de acariasis por Caparinia tripilis em ouriços Africanos, (Atelerix albiventris), na Costa Rica Andrés Moreira ${ }^{1 *}$; Adriana Troyo ${ }^{1}$; Olger Calderón-Arguedas ${ }^{1}$

${ }^{1}$ Departamento de Parasitología, Centro de Investigación en Enfermedades Tropicales, Facultad de Microbiología, Universidad de Costa Rica, San José, Costa Rica

Received February 14, 2012

Accepted April 10, 2012

\begin{abstract}
The African hedgehog is one of the newly imported exotic pets which have been observed with increasing regularity in veterinary clinics in Costa Rica. Despite their popularity, information about their diseases is scarce. Within skin diseases of hedgehogs, mange caused by Caparinia spp. is a common diagnosis in other countries. Two adult African hedgehogs, one male and one female, were brought to a private clinic in Heredia, Costa Rica, with chronic pruritic dermatitis, scabs, nearly complete loss of spines, lethargy, dehydration, and weight loss. During physical exam, deposits of dry seborrhea were taken and processed for diagnosis. Microscopic examination revealed psoroptid mites identified as Caparinia tripilis. This is the first report of the presence of Caparinia tripilis in Costa Rica and, to the authors' knowledge, the rest of Central America.
\end{abstract}

Keywords: Erinaceidae, ectoparasites, mange, Psoroptidae, Central America, African hedgehog.

\section{Resumo}

O ouriço africano é um dos animais de estimação exótico, recém-importado que tem sido observado com maior regularidade nas clínicas veterinárias da Costa Rica. Apesar da sua popularidade, informaçôes sobre suas doenças são escassas. Dentre as doenças de pele de ouriços, a sarna causada por Caparinia spp. é um diagnóstico comum nos outros países. Dois adultos ouriços africanos, um macho e uma fêmea, foram levados para uma clínica particular, em Heredia, Costa Rica, com a dermatite pruriginosa crônica, crostas, perda quase completa de espinhos, letargia, desidratação e perda de peso. Ao exame físico, os depósitos de seborreia seca foram retirados e processados para o diagnóstico. $\mathrm{O}$ exame microscópico revelou ácaros (psoroptidae) identificados como Caparinia tripilis. Esse é o primeiro relato da presença de Caparinia tripilis na Costa Rica e, para conhecimento dos autores, o resto da América Central.

Palavras-chave: Erinaceidae, ectoparasitos, sarna, Psoroptidae, América Central, Ouriço africano.

\section{Introduction}

The African hedgehog or white-bellied hedgehog (Atelerix albiventris Wagner, 1841) is one of the exotic species newly imported into Costa Rica as pets, and consult for these animals has been increasing in veterinary clinics around the country. The introduction of exotic species as pets has forced veterinarians to acquire knowledge about these new species, which makes the study of their diseases of utmost importance.

Hedgehogs harbor a large number of ectoparasites, being the most common ticks, fleas, as well as mites. Also their lack of effective grooming makes this species an ideal host for ectoparasites (FÖLDVÁRI et al., 2011). Concerning skin diseases of hedgehogs, acariasis is relatively common, although less prevalent than other ectoparasites (GERSON; BOEVER, 1983). Generally the species

\footnotetext{
*Corresponding author: Andres Moreira Soto

Departamento de Parasitología, Centro de Investigación en Enfermedades

Tropicales, Facultad de Microbiología, Universidad de Costa Rica,

Ciudad Universitaria Rodrigo Facio, CEP 11501, San José, Costa Rica

e-mail: anders2323@gmail.com
}

reported are mites that belong to the genera Sarcoptes, Notoedres, Otodectes, Chorioptes and Caparinia (FREDES; ROMAN, 2004). Within the genus Caparinia Canestrini, 1894, the most prevalent species are C. tripilis Michael, 1889, and C. erinacei Fain, 1962, but other species like C. setifera Megnin 1880, C. algirus Fain, 1979 and C. lophiomys Fain, 1975 have also been described (FAIN, 1962, 1975; SWEATMAN, 1962; FAIN; PÓRTUS, 1979).

Due to the relatively recent entry of this exotic species in the region of Central America, it is essential to report and study their parasitic species, in order to evaluate if any of these exotic parasites poses a risk for human health or infecting local fauna (FURLEY et al., 1999; PRAZERES et al., 2011).

\section{Case Description}

One male and one female African hedgehogs, Atelerix albiventris, where referred to a private clinic in the city of Heredia, Costa Rica, with a history of loss of spines, itching, lethargy and weight loss. The animals had lived together for their whole lives 

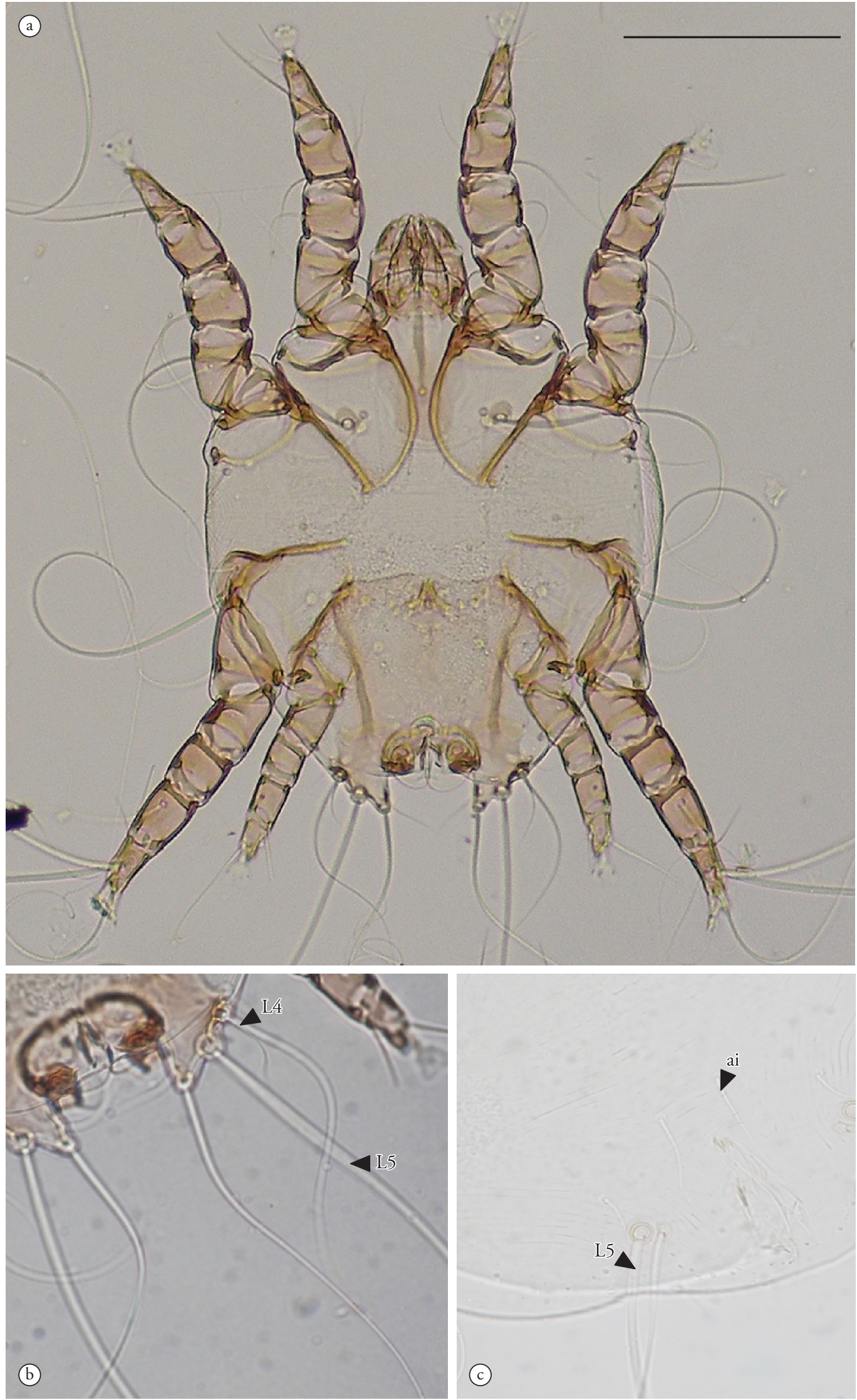

Figure 1. a) Adult Male of Caparinia tripilis (Scale bar: $100 \mu \mathrm{m}$ ). Diagnostic structures used for identification: bristles L4, L5, in b) male and bristles L5, ai in c) Female. 
(2 years approximately), and within the same enclosure. They ate commercial cat food ad libitum and yellow mealworms. The owners had observed loss of spines and scratching for several months, but had not sought treatment previously. Observations during the physical exam included extensive bilateral alopecia of the periorbital region, lateral surfaces of the head, the flanks, hind and fore limbs, abdominal area, and rump. The skin was dark grey, dry, and extremely lichenified, there were also flaky white scales in the entire dorsal surface. Sparse spines remained on the flanks. The hedgehogs were in poor nutritional condition, weighing approximately $250 \mathrm{~g}$.

Upon examination with a magnifier, moving ectoparasites were observed on most of the animals' body, with copious amounts below the crust. A skin scraping of each individual was taken for microscopic examination. The samples where obtained from several body parts: the dorsum, behind the ear, near scapular region and head. Collected material was observed first in $\mathrm{KOH} 10 \%$, to assess the presence of other pathogenic agents.

Numerous ectoparasites were observed, collected, and preserved in $70 \%$ ethanol. Some specimens were mounted in Hoyer's medium, with subsequent evaluation in light microscopy (KRANTZ; KRANTZ, 2009).

Species identification was performed with the aid of taxonomic keys and descriptions that include psoroptid genera, and species of Caparinia (FAIN, 1962; 1975; FAIN; PÓRTUS, 1979: OCONNOR, 2009).

Scrapings from both hedgehogs contained eggs, immature stages, and adults, of a psoroptid mite identified as Caparinia tripilis (Figure 1a). Identification was based on diagnostic characters such as body length, hairs ( 14 and 15 in males, and $a i$ and $l 5$ in females), and appearance of adanal suckers and posterior lobes of males (Figure 1b, c).

Hedgehogs were treated with ivermectin at $200-500 \mu \mathrm{g} / \mathrm{kg}$ topically. Although repeated administrations were advised and are usually required (MEREDITH; REDROBE, 2002), owners did not return for further treatment. Therefore, complete resolution of the mange could not be confirmed.

\section{Discussion}

In the case presented, the mite was identified as $C$. tripilis, which is usually the most prevalent species and regularly observed in pet hedgehogs (IVEY; CARPENTER, 2003; PATERSON, 2006). Up to $40 \%$ of hedgehogs held in captivity can be infested with C. tripilis (BEXTON; ROBINSON, 2003). Caparinia erinacei may also be frequent, although it is generally seen in wildlife populations (IVEY; CARPENTER, 2003).

Owners usually report $C$. tripilis mites as deposits of a white powdery material around the eyes, ears, and cheeks, associated with pruritus (PATERSON, 2006). Due to lack of knowledge, owners in this case believed that the animals had a zoonotic and non treatable disease. Moreover, they had trouble finding a veterinary clinic with exotic practice, so disease progressed for several months, ergo its severity.

Acariasis is often found with co-infection by dermatophytes (Trichophyton erinacei, Microsporum canis, and M. gypseum) or even pyoderma, complicating clinical symptoms and treatment (SWEATMAN, 1962; BROCKIE, 1974; PATERSON, 2006). However, other pathogens were not evidenced in the cases presented, neither in the physical examination nor on the skin scrapings, so co-infection was discarded.

Infestation with Caparinia spp. may or may not be accompanied by clinical signs. Some normal symptoms include scratching or rubbing against objects, but many individuals do not demonstrate obvious signs of pruritus, such as the cases presented (GERSON; BOEVER, 1983). Several factors including stress, lack of hygiene and immune dysfunction may contribute to the onset of the disease (PRAZERES et al., 2011). In the cases described, the pathology was severe and may have been exacerbated by any of these factors, and could have contributed to weight loss of the hedgehogs. Acariasis also causes nonspecific signs such as lethargy and decreased appetite (PRAZERES et al., 2011).

A study performed by Fredes and Roman (2004) reported $87 \%$ positivity for mites in skin scrapings of hedgehogs; of which, $100 \%$ were $C$. tripilis. This finding suggests that $C$. tripilis may be considered a normal skin inhabitant of hedgehogs without causing any clinical signs. However, Brockie (1974) and Fain (1975), have considered this mite a low pathogenic parasite instead of a commensal. Considering the amount of $C$. tripilis mites observed in addition to the severity of clinical signs, psoroptic mange was diagnosed in the cases presented.

Ivermectin is often used as treatment for psoroptic mange, administered both topically and or subcutaneously once per week (MEREDITH; REDROBE, 2002). In this case, treatment was initiated with the recommended dose, but continuation of the treatment and further assessment was not possible. Although repeated administrations are usually needed to eliminate $C$. tripilis effectively (MEREDITH; REDROBE, 2002), it is possible that owners did not return due to improvement of the animals' condition, or they may have sought treatment elsewhere. It is important to note that ear canals should always be checked as they may be totally impacted with mites and debris, which must be mechanically removed.

Mites are common in pet hedgehogs in the United States, Europe and New Zealand (MEREDITH; REDROBE, 2002). In contrast, information for Costa Rica and the rest of Central America is scarce. The reason for introduction of this exotic species in these countries is to keep them as domestic pets, and currently there is no information regarding their population, prevalence of this particular ectoparasite, or any other factor that may contribute to the persistence of exotic mites in tropical environments of the region. Since $C$. tripilis is considered an exotic mite that has been introduced along with its host (SWEATMAN, 1962), further studies are necessary to asses how these and other exotic ectoparasites may affect local fauna.

\section{Aknowledgements}

Authors thank Sergio Bermudez (Instituto Conmemorativo Gorgas de Estudios en Salud) for sharing his opinions and references, Geovanny Mora for processing mite samples, and Laura Bonilla 
Villanueva for Portuguese translation. This work was supported in part by University of Costa Rica project ED-548.

\section{References}

Bexton S, Robinson I. Hedgehogs. In: Mullineaux E, Best R, Cooper JE. BSAVA Manual of Wildlife Casualties. Gloucester: BSAVA; 2003. p. $49-65$.

Brockie RE. The hedgehog mange mite, Caparinia tripilis, in New Zealand. NZVet J 1974; 22(12):243-247. PMid:4549591. http://dx.doi. org/10.1080/00480169.1974.34179

Fain A. Un nouvel acarien psorique du Hérisson sud-africain: Caparinia erinacei n. sp. Rev Zool Bot Afr 1962; 5: 204-210.

Fain A. Noveaux taxa dans les psoroptinae hypothese sur l' origine de ce groupe (Acarina, Sarcoptiformes, Psoroptidae). Acta Zool Pathol Antverpiensia 1975; 61: 57-84. PMid:1163396.

Fain A, Pórtus M. Two new parasitic mytes (Acari, Astigmata) from the algerian hedgehog Aethechinus algirus in Spain. Rev Iberica Parasitol 1979; 39:577-585.

Földvári G, Rigó K, Jablonszky M, Biró N, Majoros G, Molnár V, et al. Ticks and the city: Ectoparasites of the Northern white-breasted hedgehog (Erinaceus roumanicus) in an urban park. Ticks Tick Borne Dis 2011; 2(4): 231-234. PMid:22108019. http://dx.doi.org/10.1016/j. ttbdis.2011.09.001

Fredes F, Roman D. Fauna parasitaria en erizos de tierra africanos (Atelerix albiventris). Parasitol Latinoam 2004; 59(1-2): 79-81. http://dx.doi. org/10.4067/S0717-77122004000100017
Furley JA, Suchniak J, Paller AS. Hedgehog Hives. Arch Dermatol 1999; 135(5): 561-563. http://dx.doi.org/10.1001/ archderm.135.5.561

Gerson L, Boever WJ. Acariasis (Caparinia sp.) in hedgehogs (Erinaceus spp.): diagnosis and treatment. JZoo An Med 1983; 14: 17-19. http://dx.doi.org/10.2307/20094622

Ivey E, Carpenter JW. African hedgehogs. In: Quesenberry KE, Carpenter JW, editors. Ferrets, rabbits and rodents: clinical medicine and surgery - Includes sugar gliders and hedgehogs. 2nd ed. Missouri: Saunders; 2003. p. 339-353.

Krantz DE, Krantz GW. Collecting, rearing, and preparing specimens. In: Krantz GW, Walter DE, editors. A manual of acarology. 3rd ed. Texas Tech University Press; 2009. p. 83-96.

Meredith A, Redrobe S. BSAVA Manual of Exotic Pets. 4th ed. BSAVA. England. 2002. p. 112.

Oconnor BM. Cohort Astigmata. In: Krantz GW, Walter DE, editors. $A$ manual of acarology. 3rd ed. Texas Tech University Press; 2009. p. 565.

Paterson S. Skin diseases of exotic pets. Iowa: Blackwell Publishing; 2006. http://dx.doi.org/10.1002/9780470752432

Prazeres RF, Kluyber D, Fernandes RS, Fecchio RS, Teixeira RHF, Amorim M, et al. Sarna pelo acaro Caparinia tripilis em dois porcosespinho africanos ou "hedgehogs" (Atelerix alvibentris) mantidos como animais de estimacao- primero relato no Brasil. Medvep Rev Cient Med Vet Pequenos Anim Anim Estim 2011; 9: 116-119.

Sweatman G. Parasitic mites of non-domesticated animals in New Zealand. New Zealand Entomol 1962; 3(1): 15-23. http://dx.doi.org/1 $0.1080 / 00779962.1962 .9722809$ 